ÇOMÜ Uluslararası Sosyal Bilimler Dergisi 3 (2), 363-387 , 2018

COMU International Journal of Social Sciences 3 (2), 363-387, 2018

\title{
Akıllı Ulaşım Sistemlerinin Dışsallık Bağlamında Değerlendirilmesi: Seçilmiş Ülke Uygulamaları *
}

\author{
Mehmet Emin KENANOĞLU ${ }^{\circledR}$ ** \\ Murat AYDIN ***
}

Öz

Polislerin, ilk kez ellerini kullanarak, trafiği yönlendirmeleri ile sorunları çözmeye çalışmasından bu yana uzun bir süre geçmiştir. Bu süreçte hem ulaşım araçları hem de ulaşımdan kaynaklı sorunlar farklılaşmış ve çeşitlenmiştir. Nüfus ve araç sahipliği artmış, kısa ve uzun mesafeli seyahat ve yük taşıma eğilimi yükselmiş, ulaşım alanında konfor, güvenlik, hız gibi beklentiler çoğalmıştır. Beklentiler ve gerekliliğin artmasıysa; ekonomik performans, güvenlik, hareketlilik ve çevresel sürdürülebilirliği geliştirmek için ulaşım altyapısı ile bilgi ve iletişim teknolojilerinin uyumunu zorunlu kılmıştır. Bilgi ve teknolojinin, ulaşımın her alanına uygulanması ise ulaşım sistemlerinin akıllı sıfatını kazanmasını sağlamıştır. Ulaşım sistemlerinin akıllı hale gelmesi, gerçekleşen ekonomik faaliyetlerin alıcı ve satıcının yanı sıra üçüncü kişiler üzerinde de fiyatlandırılmamış yan etkiler doğurmasına neden olmuştur. Bu etkiler yararlı olduğunda pozitif, zararlı olduğunda negatif dışsallıklar ortaya çıkmaktadır. Akıllı Ulaşım Sistemi sayesinde insan kaynaklı hatalar minimize edilerek trafik kaynaklı üçüncü kişilerin zaman kaybı, ölümü, kazalar esnasında yaralanması, maddi kayıpları, stres yaşamaları, sağlık sorunları ve hava kirliliği gibi birçok negatif dışsallığın önüne geçilebilmektedir. Bu çalışmanın amacı, yazın taraması kapsamında, Avrupa Birliği ve çeşitli ülkelerin (Avustralya, Singapur, Japonya, Amerika Birleşik Devletleri gibi) Akıllı Ulaşım Sistemleri ve Hizmetlerini

* $\quad$ Bu çalışma, Çanakkale Onsekiz Mart Üniversitesi, Sosyal Bilimler Enstitüsü, Maliye Ana Bilim Dalı’nda hazırlanan "Akıllı Ulaşım Sistemleri ve Dışsallık: Çanakkale Örneği” adlı tez çalışmasından türetilmiştir. Çanakkale Onsekiz Mart Üniversitesi, Bilimsel Araştırma Projeleri kapsamında (Proje No: SYL-20171274) desteklenmiştir. Ayrıca, 08-12 Mayıs 2018 tarihlerinde Antalyada düzenlenen 33. Uluslararası Maliye Sempozyumu’nda İngilizce genişletilmiş özet bildiri olarak "Evaluation of Intelligent Transportation Systems Applied in Various Countries in the Context of Externality” başlı̆̆ı altında sunulmuştur.

(C) Sorumlu Yazar / Corresponding Author

** Arş. Gör., T.C. Çanakkale Onsekiz Mart Üniversitesi, Biga İktisadi ve İdari Bilimler Fakültesi, Maliye Bölümü, mehmeteminkenanoglu@comu.edu.tr

*** Doç. Dr., T.C. Çanakkale Onsekiz Mart Üniversitesi, Biga İktisadi ve İdari Bilimler Fakültesi, Maliye Bölümü, murataydin@comu.edu.tr 
inceleyerek (nedenlerini, uygulamalarını ve çıktılarını) ne tür dışsallıklara sebep olduklarını ortaya koyarak, konunun önemini (insan, çevre ve ulaşım bazlı olması nedeniyle) vurgulayarak bu tür sorun yaşayan ülkelere çözüm önerilerinde bulunmak olmuştur.

Anahtar Kelimeler: Avrupa Birliği, Akıllı Ulaşım Sistemleri, Dışsallık.

\title{
Evaluation of Intelligent Transportation Systems in the Context of Externality: Selected Country Applications
}

\begin{abstract}
The problem of traffic congestion was first solved by the policemen who attempted to direct traffic by using their hands. It has been a long time since they tried to solve the traffic problems by this way. Both transportation means and problems related to transportation have been differentiated and diversified in the progress of transportation systems. Population and vehicle ownership, short and long distance travel and load-bearing tendencies have increased. Therefore, in the area of transportation, expectations as comfort, security and speed have increased. Transportation infrastructure and information and communication technologies have to be harmonized to improve economic performance, security, mobility and environmental sustainability by increased expectations and necessities. Information and technology are applied to all areas of transportation. Thereby, transportation systems provide to get smart qualities. The actual economic activity caused untested side effects on not only the supplier and costumer but also third parties. If the effects are beneficial, positive externalities occur and if the effects are harmful, negative externalities occur. By means of Intelligent Transportation Systems, many negative externalities such as time loss, death, injury during accidents, financial loss, stress, health problems and air pollution caused by traffic can be prevented by minimizing human mistakes. The aim of the paper was to propose solutions to the problem of traffic congestion by investigating country cases, namely European Union and various other countries (Australia, Singapore, Japan, the United States). The study also discusses the importance of the subject (with respect to human, environment and transportation roots) by putting forward the possible externalities that these applications cause in the cases of intelligent transportation systems and services (causes, applications and their outputs).
\end{abstract}

Keywords: European Union, Intelligent Transportation Systems, Externality. 


\section{GİRIS}

Nüfus ve araç sahipliğindeki artış, seyahat eğilimlerindeki yükseliş, yolcu ve yük taşımacılığına olan talepteki yoğunlaşma gibi birçok faktör her geçen gün ulaşımın önemini arttırmaktadır. Ulaşımın önemindeki artışsa ister istemez daha hızlı, güvenli, ucuz, çevreci, sürdürülebilir bir ulaşım sistemi gereksinimini doğurmaktadır. Sürdürülebilir bir ulaşımsa, verimlilik ve etkinliği ön plana çıkararak; enerji tüketiminin azaltılması, iş kaybının önlenmesi, rekabetin arttırılması, arazilerin verimli ve etkin kullanılması, kazaların önlenmesi, stresin azaltılarak birçok hastalığın önüne geçilmesi gibi birçok pozitif dışsallığın ortaya çıkmasını sağlamaktadır.

Ulaştırma alanında yaşanan birçok negatif dışsallığın önüne geçmek ya da pozitif dışsallıkları ortaya çıkarmak adına güvenlik, hareketlilik, ekonomik verimlilik ve çevresel sürdürülebilirliği geliştirmek için ulaşım altyapısı ile bilgi ve iletişim teknolojilerinin uyumunun sağlanması gerekmektedir. Yani ulaşımın, bilgi ve teknolojiyle uyumunun sağlanarak Akıllı Ulaşım Sistemi (AUS) ve hizmetlerinin uygulamaya sokulması sağlanmalıdır. Çünkü AUS, ulaşım esnasında insanın düşünme ve karar verme yükünü hafifleterek birçok olumsuzluğun önüne geçebilmektedir.

AUS, ulaşım alanına; güvenlik, verimlilik, sürdürülebilirlik gibi birçok alanda pozitif çıktı sağlayarak yeni bir soluk getirmektedir. Bu da ister istemez Avrupa Birliği (AB) ülkeleri de dâhil olmak üzere birçok ülkede AUS konusunda yenilikçi yaklaşımlar uygulanmasını gündeme getirmiştir. Örneğin: AB, 2010/40/EU direktifleri, karayolları taşımacılı̆̆ında AUS’u yaygınlaştırmıştır.

Bu çalışmanın amacı, yazın taraması kapsamında çeşitli ülkelerde uygulanan AUS’un incelenerek, yaygın bir şekilde uygulamaya geçirilmesinin ortaya çıkaracağı pozitif ve negatif dışsallıkların neler olabileceğini ortaya koymaktır. Özellikle AUS sağlanacak pozitif çıktıların günümüzün önemli sorunlarından olan "ulaşım” ve "çevre” konularına önemli katkı sağlayacağı ortaya konulmuştur. Bu kapsamda çalışmanın ilk kısmında, AUS’a dair kavramsal tanımlar, AUS türleri, AUS’un tarihi ve AUS’un kullandığı teknolojiler incelenmiştir. İkinci kısımda ise dişsallık ile ilgili kavramsal çerçeve işlenmiştir. Üçüncü bölümde ise AUS ve dişsallık ilişkisi kurulmuştur. Dördüncü bölümde ise AUS’un ortaya çıkardığı dışsallıklar ülke uygulamaları temelinde detaylı olarak tartışılmıştır.

\section{ULAŞIM VE AKILLI ULAŞIM SİSTEMİ}

Ulaşım, bir yerden başka bir yere yük veya yolcu taşımayı, başka bir deyişle "insanların ve eşyaların yer değiştirmesi ve bunun organizasyonu" ifade etmektedir. Bu noktada ulaşım faaliyetinin sağlanması; kara, hava, demir ve deniz yolu olmak üzere her biri farklı işlevsel özelliğe sahip, farklı güvenlik özellikleri taşıyan yollarla gerçekleştirilmektedir (Möller ve Vakilzadian, 2016: 776; Saatçioğlu ve Yaşarlar, 2002: 117). Ulaşım, insan yaşamı için vazgeçilmez olup, gündelik yaşama hareketlilik sağlamakla kalmamakta ayrıca insanları, ülkeleri birbirine bağlayarak mal ve hizmetlerin değişimini de kolaylaştırmakta ve bu 
sayede yüksek bir yaşam kalitesinin de önemli bir ön koşulunu yerine getirmektedir (Statistisches Bundesamt, 2013: 4).

Yüksek yaşam kalitesini sağlamak adına ulaşım, bulunulan dönem koşullarına uygun olarak tarihsel süreçte çeşitli yollarla gerçekleştirilmiştir. Antik ve Orta Çağlardan Sanayi Devrimine kadar olan dönemde yaya olarak; Sanayi Devrimi ile birlikte konut ve işyerlerinin birbirinden uzaklaşması neticesinde atlarla; buharlı makinelerin kullanılmasıyla makineler ile hızlı bir ulaşım sistemi kullanılmaya başlanmıştır (Benk, 2007: 47; Saatçioğlu ve Yaşarlar, 2012: 120-121). Ulaşım, tarım veya sanayi gibi mal üreten bir sektör değildir. Fakat sektörün etkinliği diğer sektörlerin de etkin olmasına doğrudan ve/veya dolaylı yollarla hizmet etmektedir (Akgüngör ve Demirel, 2004: 424). Çünkü bir ülkenin ulaşım sektörünün gelişmişlik durumu, ulaştırma maliyetleri ile iç ve dış pazara erişim derecesini belirleyerek ülkenin ekonomik kalkınmasına da ciddi katkılarda bulunmaktadir (Republic of Turkey Ministry of Transport and Communications, 2011: 2). Ulaşım sektörü, toplumsal yapıyı tetikleyen, üretim sürecinde önemli bir yere sahip olmasının yanında büyük çaplı yatırımlar içinde olmazsa olmaz niteliktedir (T.C. Ulaştırma Bakanlığı (UB), 2011: 14).

Ulaşım sektörü için teknolojik gelişmeler itici güçtür. Çünkü bu tür gelişmeler birçok alanda olduğu gibi ulaşım sektörünü de değişime sürükleyerek, ilerleme göstermesine yani kalite artışına neden olmaktadır. Ulaşımda kalitenin artmasıysa yaşamı etkilemektedir (Kumar vd., 2005: 2). Çünkü ulaşım alanında yaşanan pozitif değişmeler, başta seyahat konforu olmak üzere yakıt tüketimi, hava kirliliği, gürültü kirliliği ve çevre kirliliği gibi birçok alana olumlu yansımaktadır. Bazılarına göre, ulaşım sistemini iyileştirmek için sadece yeni yollar ve kavşaklar yapmak, ya da eskiyen altyapıyı tamir etmek tek başına yeterli olarak ifade edilmektedir. Bu da ulaşım sisteminin geleceğini çok basite indirgemekte (beton ve çelik temeline) ve ortaya çıkardığı birçok negatif dişsallığı da görmezden gelmektedir. Oysa olması gereken ulaşım sisteminde eski ile yeniyi, gereksinimlere göre çevre merkezci yaklaşım temelinde harmanlayarak var olan sorunları minimize etmektir. $\mathrm{Bu}$ da ister istemez ulaşım sisteminin işleyişi hakkında bilgi toplayan, topladığı bilgileri yayan sensörler, mikroçipler ve iletişim cihazları ağı gibi birçok teknolojinin de birlikte uygulanmasını gerektirmektedir (Ezell, 2010: 8). Yüksek teknolojilerle desteklenmiş, trafik yönetimini ve farklı ulaşım modlarını içeren ilgili yenilikçi servisleri sağlayarak özellikle insanın düşünme veya karar verme yükünü hafifletmeyi amaçlayan AUS’un varlığını gerektirmiştir (T.C. Ulaştırma, Denizcilik ve Haberleşme Bakanlığı (UDHB), 2014: 12; Yan vd., 2012: 321). AUS’un hayata geçmesi ise yeni olmayıp, 1960'lı ylllara (elektronik değişken mesaj işaretleri, kırmızı ışık kameralar gibi) dayanmaktadır. 1960'ların sonu ve 1970’lerin başında ise AUS araştırmaları döneminin başladığı kabul edilmektedir. AUS’un yaygınlaşması 1980 sonrası internet ve bilgisayar gibi iletişim teknolojilerinin gelişmesi ile hızlanmıştır. 1990'lı yıllara gelindiğinde ise AUS birçok ülkede önem kazanmış, ulusal ve küresel bazda koordinasyonu sağlamak için AUS birlikleri kurulmuştur (UDHB, 2014: $3,11)$.

AUS, bünyesinde küresel konum belirleme servisi (GPS), 4G teknolojisi, tahsis edilmiş 
kısa mesafeli iletişim teknolojisi, kapalı devre televizyon sistemleri, kablosuz ağlar, mobil telefonlar, radyo ve televizyon, jiroskop, LED teknolojisi gibi birçok teknolojiyi harmanlayarak ulaşımının birçok alanında kullanmaktadır (Ezell, 2010: 9). AUS’un başlıca teknolojik unsurlarından bazılarını vermek gerekirse şöyledir (European Commission, 2010: 5);

- Kısa ve uzun menzilli veri alışverişi için çeşitli kablosuz iletişim biçimleri: ultra yüksek frekans, çok yüksek frekans, mikrodalga erişimi için dünya çapında birlikte çalışabilirlik teknolojisi, mobil iletişim için küresel sistem (GSM) vb.,

- Hesaplamalı teknolojiler: mevcut eğilim daha az ve maliyetli, doğru model tabanlı süreç kontrolü ve yapay zekâ gibi daha karmaşık uygulamalara izin veren mikroişlemciler,

- Algılama teknolojisi: hem araç temelli veriler (radar, radyo frekansı tanımlama cihazı okuyucuları, kızılötesi ve görünür bant kameralar gibi cihazlar) hem de altyapı tabanlı veriler (aynı cihazdan gelen endüktif veya basınçlı sensörlere monte edilmiş veya yolun etrafına gömülmüş cihazlar) şeklinde sıralanmaktadır.

Literatürde AUS kavramına dair birçok tanıma erişmek mümkündür. Bu tanımlardan bazıları şöyledir. Shaheen ve Finson'a göre; "AUS, güvenliği, verimliliği ve tüm ulaşım ağını rahatlatmayı amaçlayan elektronik, bilgi işlem, kablosuz ağlar gibi geniş çaplı teknolojilerden meydana gelen sistemin bütününü" ifade etmektedir (Shaheen ve Finson, 2013: 2). Ramos vd. göre de "AUS, güvenliği ve hareketliliği arttıran, trafik yoğunluğu ve trafiğin ortaya çıkardığı negatif çevresel etkilerin azaltılmasını sağlayan sistemlerden oluşmaktadır" (Ramos vd., 2012: 274-275). Eicher'e göre ise AUS, bilgi ve iletişim teknolojilerini kullanarak, trafikle ilgili veri ve bilgileri toplama, işleme, aktarma ve değiş tokuşunu gerçekleştiren uygulamalardır (Eicher, 2015: 9). Avrupa Komisyonu'na göre de AUS ve hizmetleri tüm Avrupa vatandaşlarının yararı için ekonomik performans, güvenlik, mobilite ve çevresel sürdürülebilirliğini geliştirmek için ulaşım altyapısı ile bilgi ve iletişim teknolojilerinin uyumunu ifade etmektedir (European Commission, 2010: 5).

AUS, uygulaması ile birlikte birçok sistem ayrı ayrı ya da birlikte uygulanmaktadır. Bu sistemler; ileri trafik yönetim sistemleri, ileri yolcu bilgi sistemleri, toplu taşıma sistemleri, elektronik ödeme sistemleri, yük ve filo yönetim sistemleri, sürücü destek ve güvenlik sistemleri ile kaza ve acil durum sistemleri olarak sıralanmaktadır (Ramos vd., 2012: 275).

AUS neticesinde ise değişken mesaj işaretleri, sürücüsüz araçlar, hız uyarı sistemleri, yeşil dalga sistemleri, sinyalizasyon sistemleri, yol üstü kamera sistemleri, çarpışma önleme sistemleri, hareketli tartım sistemleri, şerit kontrol ve yanal destek sistemleri olarak gündelik yaşamda yerini almaktadır (Arucu, 2017: 28). Bu da ister istemez düşünme ve karar verme noktasında (sürüş esnasında, sürücünün birden çok görev üzerinde yoğunlaşması, ilgi ve yeteneğin değişen seviyelerde olması) birçok kararı bilgi sistemine bağlanması neticesinde pek çok negatif dışsallı̆̆ın önüne geçilmesine ya da pozitif 
dışsallıklar ortaya çıkmasına sebep olmaktadır.

\section{DIŞSALLIK}

Bir piyasa işleminde alınacak bir ekonomik kararın, alıcısı ve satıcısı dışında başka bireyleri de olumlu veya olumsuz etkilemesi sonucu dışsallık ortaya çıkmaktadır (Conway, 2015: 107). Burada eğer bir ekonomik birimin refahı (fayda ya da maliyet) piyasa koşulları dışında, ekonomideki bir başka birimin (tüketici ya da üreticinin) eyleminden doğrudan etkileniyorsa (Hindriks ve Myles, 2013: 224; Klarl, 2013: 4; Übelmesser, 2009/2010: 2; Hyman, 1993: 91) bir dışsallık oluştuğu ifade edilmektedir. Çünkü burada yaratılan bir faaliyet, piyasa mekanizması dışındaki başka birimleri etkilemektedir (Rosen, 2005: 107). $\mathrm{Bu}$ da üçüncü kişilere maliyetler yüklerken onların zararlarını telafi etmeyeceği, fayda sağlarken de onları fiyatlandıramayacağı anlamına gelmektedir (Stiglitz, 1994: 92).

Dişsallık konusuna ilk değinen kişinin Adam Smith olduğu ifade edilmektedir. Zira "Ulusların Zenginliği" ya da "Milletlerin Zenginliğì" adlı eserinde özel faydadan daha fazla sosyal faydaya yer vermiştir. Smith’ten sonra Alfred Marshall, içsel ekonomilerin yanı sıra dişsal ekonomilere de değinen kişi olmuştur (Sönmez, 1987: 123). Bu nedenle dişsallık kavramının ilk teorik çerçevesinin genel kabul görür şekilde Alfred Marshall tarafından oluşturulduğu ifade edilmektedir (Prendergast, 1993: 455). Sistematik incelemelerin ise ilk defa 1920 yllında Arthur Cecil Pigou'nun "Refah Ekonomisi” adlı eserinde ele alınmıştır (Geßner und Weinreich, 1998: 22; Durmuş, 2008: 195). Pigou, dışsallıkların pozitif olabileceği gibi negatif olabileceğini de ifade ederek etkinlik ve toplumsal refah ekseninde konuyu ele almıştır (Öz ve Buyrukoğlu, 2012: 86).

Dışsallıklar kavramı yazında farklı şekillerde sınıflandırılmaktadır. Bunlar; pozitif-negatif, üretim-tüketim, marjinal-inframarjinal ve parasal-teknolojik dişsallıklar şeklindedir (Rosen, 2005: 103). Bu çalışmada konu esas itibariyle pozitif ve negatif dişsallıklar bağlamında ele alınacaktır. Çünkü dışsallık konusu genel manada pozitif-negatif dışsallıklar üzerine yoğunlaşmıştır.

\section{- Pozitif (Olumlu) Dışsallıklar}

Bir malın üretiminde ya da tüketiminde, bu malla doğrudan ilişkisi olmayan üçüncü kişiler bundan olumlu ya da olumsuz olarak etkilenebilmektedir (Durmuş, 2008: 196). Eğer burada başka bir ekonomik birim yani üçüncü kişi bundan dışsal fayda sağlıyorsa bu pozitif bir dişsallık olarak ifade edilmektedir (Beckett-Camarata, 2005: 135; Karg1 ve Yüksel, 2010: 187). Yani mal ya da hizmet tüketimi sonucu ortaya çıan özel faydanın yanı sıra bir de toplumsal faydası söz konusudur (Kirmanoğlu, 2014: 159).

\section{- Negatif (Olumsuz) Dışsallıklar}

Bir malın üretiminde ya da tüketiminde, bu malla doğrudan ilişkisi olmayan üçüncü 
kişiler bundan olumsuz olarak etkileniyorsa negatif dişsallık söz konusudur (Durmuş, 2008: 196). Yani bir üretim ya da tüketim kararının neticesinde ortaya çıkan özel maliyetin yanı sıra bir de dişsal maliyet söz konusuysa negatif dışsallık ortaya çıkmaktadır. Negatif dışsallıklar varlığında, mal ya da hizmet üretimi sonucunda piyasa işleminin dışında diğer firmalara veya toplumunun tamamına yayılan negatif bir etki söz konusudur (Kirmanoğlu, 2014: 161).

\section{AKILLI ULAŞIM SİSTEMLERİ VE DIŞSALLIK İLIŞKİSI}

Ulaşımı birçok hizmetten ayıran temel özelliklerinden birisi depolanamamasıdır. Örneğin, tarım ve sanayi mallarında olduğu gibi daha fazla üretip, depolanma şansı yoktur. Bu da ihtiyaç duyulduğunda ihtiyacı karşılayacak düzeyde sunulmasını gerektirmektedir (Akgüngör ve Demirel, 2004: 424). İhtiyaçtan az üretildiğinde; zaman, para, stres, iş kayb1, rekabette dezavantaj gibi birçok olumsuzluğa neden olurken, ihtiyaçtan fazla üretildiğinde de depolanamamasından kaynaklı para ve enerji kaybı ve çevresel kirlilikler gibi yine birçok negatif dışsallı̆̆

Ulaşım hizmetinin eksik veya fazla üretilmesinden kaynaklı negatif dışsallıkların önüne geçmek için ulaşımın rasyonel planlanması, yönetimi ve kullanımını gerektirmektedir. Ulaşım alanında rasyonel kararlar almanın yolu da bilgi teknolojilerinden geçmektedir. Çünkü ulaşım alanında bilgi ve teknolojilerin yaygın kullanımı bu alanda yaşanabilecek birçok negatif dışsallığı azaltabilecek ya da ortadan kaldırabilecek niteliktedir. Bu noktada AUS hizmet ve uygulamaları ön plana çıkmaktadır. Sadece karayollarında güvenliği arttırma, trafik sıkışıklığını azaltma, yolcu ve yüklerin mobilitesini arttırma gibi kazanımlarından dolayı bile AUS, ulaşım alanına heyecan getirmiştir (Barth vd., 2015: 1). Ancak AUS’tan tam kapasite ile verim almak için AUS’u kara, hava, demir ve deniz yolu olmak üzere tüm ulaşım alanlarına uygulamak ve bu ulaşım alanları arasındaki bütünlüğü sağlamak gerekmektedir. Zira AUS ile insanın düşünme veya karar verme yükü birçok alanda hafifletilerek, hata payı düşürülmektedir. Bu sayede AUS, trafikte meydana gelen insan kaynaklı kusurları ortadan kaldırarak veya en azından minimize ederek trafikte meydana gelen negatif dışsallıkların azaltılması, pozitif dışsallıkların ise arttırılmasında önemli rol oynamaktadır. Uluslararası Standartlar Organizasyonu (ISO)'nun Tablo 1'de yer alan sınıflandırması bu durumu daha iyi anlatmaktadır. 
Tablo 1: Akıllı Ulaşım Sistemi’nin Mimarisi, Hizmet Alanları ve Sınıflandırması

\begin{tabular}{|c|c|}
\hline Hizmet Alanları & Hizmet Grupları \\
\hline Yolcu bilgisi & $\begin{array}{l}\text { - Ön seyahat bilgisi } \\
\text { - Seyahat halindeki bilgi } \\
\text { - Seyahat hizmetleri bilgisi } \\
\text { - Seyahat öncesi yol rehberi ve navigasyon } \\
\text { - Seyahat esnasinda yol rehberi ve navigasyon } \\
\text { - Seyahat planlama desteği }\end{array}$ \\
\hline Trafik yönetimi ve işlemleri & $\begin{array}{l}\text { - Trafik kontrol } \\
\text { - Ulaşımla bağlantılı kaza yönetimi } \\
\text { - Talep yönetimi } \\
\text { - Ulaşım altyapısı bakım yönetimi }\end{array}$ \\
\hline Araç & $\begin{array}{l}\text { - Ulaşımla ilgili vizyonun iyileştirilmesi } \\
\text { - Otomatik araç işlemi } \\
\text { - Çarpışmadan kaçınma } \\
\text { - Güvenlik } \\
\text { - Çarpışma öncesi engelleme }\end{array}$ \\
\hline Nakliye ulaşımı & $\begin{array}{l}\text { - Ticari araç̧ön izni } \\
\text { - Ticari araç idari işlemleri } \\
\text { - Otomatik yol kenarı güvenlik denetimi } \\
\text { - Ticari araç kabininde güvenlik izleme } \\
\text { - Nakliye ulaşımı filo yönetimi } \\
\text { - Çoklu model bilgi yönetimi } \\
\text { - Çoklu model merkezlerinin yönetimi ve kontrolü } \\
\text { - Tehlikeli nakliye araçlarının yönetimi }\end{array}$ \\
\hline Toplu taşıma & $\begin{array}{l}\text { - Toplu taşıma yönetimi } \\
\text { - Talebe duyarli toplu taşıma }\end{array}$ \\
\hline Acil durum & $\begin{array}{l}\text { - Ulaşımla ilgili acil durum uyarıları ve kişisel güvenlik } \\
\text { - Acil araç yönetimi } \\
\text { - Tehlikeli materyal ve kaza duyuruları }\end{array}$ \\
\hline Ulaşımla ilgili elektronik ödeme & $\begin{array}{l}\text { - Ulaşımla ilgili elektronik finansal işlemler } \\
\text { - Ulaşımla ilgili elektronik ödeme sistemlerinin entegras- } \\
\text { yonu }\end{array}$ \\
\hline $\begin{array}{l}\text { Karayolu ile ilgili kişisel güven- } \\
\text { lik }\end{array}$ & $\begin{array}{l}\text { - Toplu seyahat güvenliği } \\
\text { - Seyahat edenlerin güvenliğinin artırılması } \\
\text { - Engellilerin yol güvenliğinin artırılması } \\
\text { - Akıllı kavşak ve bağlantılar }\end{array}$ \\
\hline $\begin{array}{l}\text { Hava ve çevresel durumları iz- } \\
\text { leme }\end{array}$ & $\begin{array}{l}\text { - Hava durumu izleme } \\
\text { - Çevre koşullarını izleme }\end{array}$ \\
\hline $\begin{array}{l}\text { Afet müdahale yönetim ve koor- } \\
\text { dinasyonu }\end{array}$ & $\begin{array}{l}\text { - Afet veri yönetimi } \\
\text { - Afet müdahale yönetimi } \\
\text { - Acil durum merkezlerinin koordinasyonu }\end{array}$ \\
\hline Ulusal güvenlik & $\begin{array}{l}\text { - Şüpheli araçların izlenmesi ve kontrolü } \\
\text { - Stratejik yerlerin izlenmesi (petrol boru hattı) }\end{array}$ \\
\hline
\end{tabular}

Kaynak: (T.C. Ulaştırma, Denizcilik ve Haberleşme Bakanlığı, 2014: 18). 
Tablo 1'de yer alan AUS hizmet alanları ve grupları göz önüne alındığında AUS’un ortaya çıkardığı dışsallıkların sadece pozitif yönde etkili olduğu düşünülmektedir. Ancak AUS’un ortaya çıkardığı dışsallıklar pozitif olabildiği gibi negatif yönlüde ortaya çıkabilmektedir. AUS’un ortaya çıkardığı pozitif ve negatif dışsallıklar başlık 3.1 ve 3.2'de detaylı olarak tartışılmıştır.

\subsection{Akıllı Ulaşım Sistemleri ve Ortaya Çıkardı̆̆ı Pozitif Dışsallıklar}

Yolcu bilgi sisteminden, nakliye ulaşımına, acil durumdan, ulusal güvenliğe kadar birçok alana AUS’un uygulaması neticesinde pozitif çıktılar almak mümkündür. Çünkü ulaşım; ekonomik, sosyal ve çevresel maliyetlerle ilişkilendirilebilmektedir (Nilsson vd., 2012: 722-723). Ana hatları ile AUS pozitif çıktılarını vermek gerekirse Şekil 1'deki gibidir.

\section{Şekil 1: Akıllı Ulaşım Sisteminin Pozitif Çıktıları}

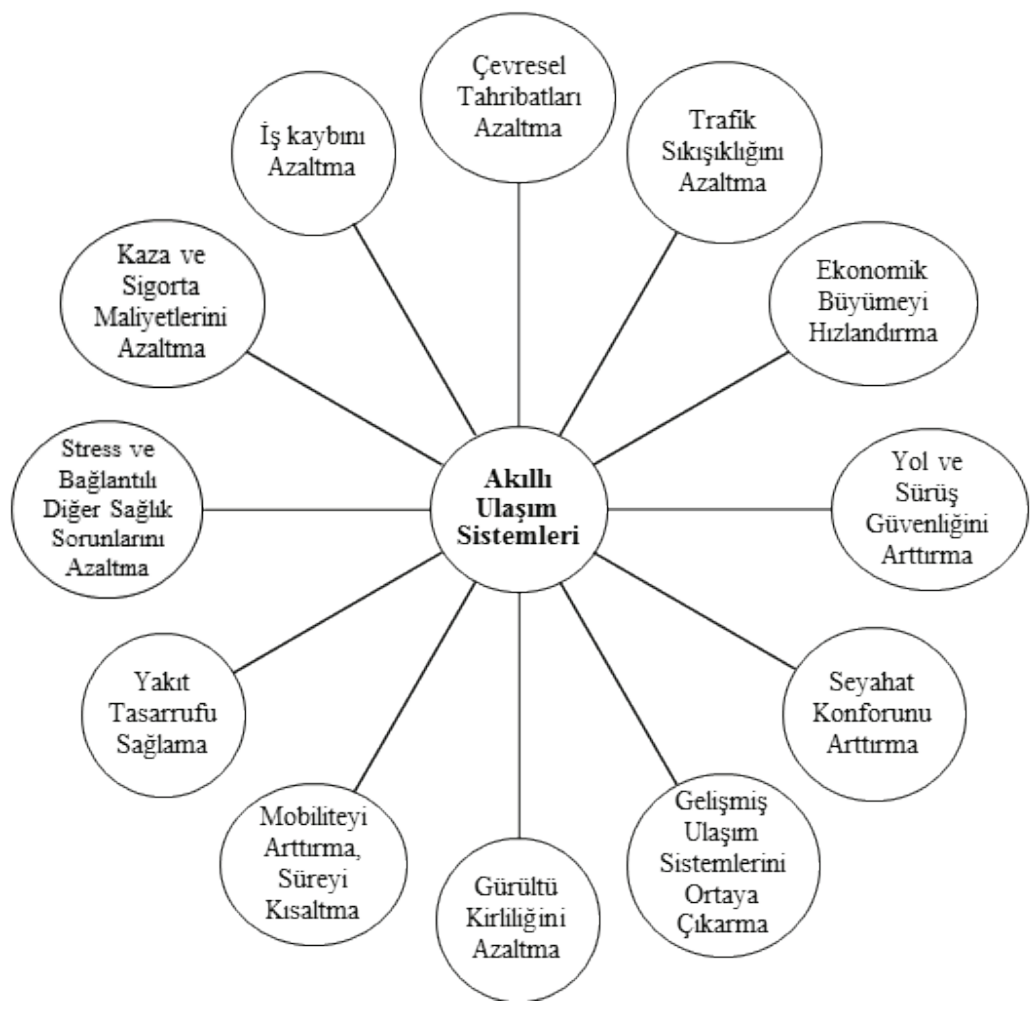

Kaynak: Yazarlar tarafından oluşturulmuştur.

Trafik yoğunluğunda yaşanan artış, gürültü ve hava kirliliği gibi çevresel kirlilik alanında yaşanan olumsuzluklar, yolcu ve yük hizmetlerinin zamanında ulaştırılması ile ulaşım 
alanında konfor ve güvenlik beklentisi gibi birçok sorun aslında bu sorun ve beklentilere karşı çözümlerinde üretilmesini zorunlu kılmaktadır. Ulaşım alanına entegre edilecek AUS ise başta seyahat süresinin düşürülmesi, trafik ile alakalı tıkanıklıkların azaltılması, yaşam kalitesinin arttırılması ve yakıt tüketiminin en aza indirilmesi gibi birçok alanda önemli avantajlar sağlayabilmektedir (Turner ve Uludag, 2016: 1261). Ayrıca ekolojik denge korunacak, yol ve sürüş güvenliğini arttırarak, ulaşım sistemlerinin gelişmesine katkı sağlanarak, gürültü başta olmak üzere birçok negatif dışsallığın da önüne geçilebilecektir.

AUS'un yaygın kullanılması sonucunda üretici ya da tüketicinin kendisine yönelik sağlayacağı fayda veya katlanacağı maliyetlerin yanı sıra üçüncü kişilere yönelik sağlayacağı dışsallıklar da önemli olmaktadır. Çünkü trafik yoğunluğunun azaltılması başta kişiye ya da firmaya zaman ve yakıt tasarrufu gibi avantajlar sağlayacaktır. Ancak beraberinde fiyatlandırılamayan, üçüncü kişilere de kazanımları söz konusu olacaktır. Bu kazanımlar; gürültü, görüntü, hava kirliliği gibi çevresel kirliliklerin azaltılmasına da katkı sağlayacaktır. Ayrıca ülke ekonomisine de yakıt tüketiminin azaltılmasından kaynaklı dış ticaret ve cari dengesine katkı sağlayarak, kaynakların israfını önleyerek ya da kirletilen çevreyi temizleme maliyetlerini azaltacak avantajlar sağlayacaktır. Zira sürdürülebilir hareketlilik, hem bir ülkenin ekonomik büyümesi ve refahı, hem de halkının refahı için bir ön koşuldur (ITS Deutschland, 2017: 3).

\subsection{Akıllı Ulaşım Sistemleri ve Ortaya Çıkardı̆̆ı Negatif Dışsallıklar}

AUS'un ortaya çıkardığı pozitif dışsallıklar oldukça önemli boyutlara ulaşmıştır. Zira Şekil 1'de de görüldügüü üzere AUS’un ortaya çıkardığı pozitif dışsallıklar açıkça görülmektedir. Ancak burada tartışılması gereken bir başka nokta ise AUS'un ortaya çıkarabileceği negatif dışsallıkların da olabileceği gerçeğidir. Çünkü teknoloji kullanımının bu denli artması pozitif dışsallıkların yanı sıra negatif dışsallıklarında meydana gelmesine neden olmaktadır. AUS’un yaygın kullanımı sonucu ortaya çıkacak negatif dışsallıklar şöyledir;

- Her şeyin teknolojik hale gelmesi neticesinde kişisel mahremiyet noktasında sorunlarla karşılaşılabilmektedir. Bu durum kişinin kendisini etkileyebileceği gibi ailesini ya da başka kişileri de etkileyebilecek niteliktedir.

- Teknoloji kaynaklı ortaya çıkabilecek güvenlik açıkları yoğun kullanımla birlikte artacaktır. Akıllı teknoloji mahsulü ürünler ile sistemlerinde güvenlik açıklarının her an ortaya çıkma riskinin olması (Bayless vd., 2014: 7), bunlarla bağlantılı kaza, hırsızlık, gibi birçok negatif dışsallığı da ortaya çıkaracaktır. AUS uygulamalarınca elde edilen tüm kişisel ve toplumsal bilgilerin sanal ortamda, art niyetli kişilerce ele geçirilme olasılığı ise bir başka sorunu oluşturmaktadır.

- AUS kullanımının yaygınlaşması ile birçok işlemin otomasyona bağlanması, belli alanlarda kişisel becerilerin sürekli kullanılmamasına bağlı olarak kişisel becerilerin zayıflaması ya da ortadan kalkmasına neden olacaktır. 
- Yoğun teknoloji kullanımı, kişiler arasındaki iletişim isteğini düşürerek (mobil uygulamalar, elektronik paneller veya otomasyon sistemleri) kişisel ilişkileri zayıflatacaktır.

- AUS uygulamalarının yaygın kullanımı, teknolojik cihazların (örneğin verici istasyonlarından yayılan radyasyon gibi) ortaya çıkardığı birçok sağlık problemini arttıracaktır.

- AUS’un kendisinin geri dönüşümünün sağlanamaması halinde çevrenin teknoloji çöplüğüne dönüşmesi muhtemeldir.

- AUS, birçok alanda emeğin yoğun kullanımını azaltacağı için işsizliğe de sebep olacaktır. İşsizlik ise kişiyi etkilemesinin ötesinde, ailesini, çevresini ve tüm toplumu etkileyerek sosyal sorunları da beraberinde getirecektir.

\section{AKILLI ULAŞIM SİSTEMLERİ VE ÜLKE UYGULAMALARI}

İnsanın trafikteki düşünme ve karar verme yükünü hafifleten bilgi ve iletişim destekli ulaşım çözümleri şeklinde lanse edilen AUS’un; AB, Avustralya, Singapur, Birleşik Krallık, Hindistan, Japonya, Güney Kore, Çin ve Amerika Birleşik Devletleri (ABD) uygulamaları incelenmiştir. Söz konusu ülkelerden Avustralya, Singapur, Japonya, Güney Kore ve ABD’nin seçilmesinde bu teknolojilerde uzmanlaşmış olmaları; ortak kültürel ve tarihi mirasa sahip olan bir çatı niteliğindeki $\mathrm{AB}$ ve bu birlikten ayrılma sürecinde olan Birleşik Krallık; ayrıca nüfus ve ekonomik potansiyellerinin yüksek olması bakımından önemli olan iki ülke yani Hindistan ve Çin incelenmiştir.

Avrupa için ekonomik ve ulaşılabilir bir ulaşımın, sürdürülebilir servet ve refah için bir temel oluşturduğu açıkça ifade edilmektedir (European Commission, 2010: 5). Örneğin, AB üyesi olan, Avusturya’nın ulaştırma sisteminin etkinliğinin, ekonomilerinin rekabet gücü ve vatandaşların yaşam kalitesi için çok önemli bir faktör olduğu, son 50 yıllık deneyimlerinin de ekonomik büyüme ve trafik gelişiminin yakından bağlantılı olduğu belirtilmiştir (Böhm vd., 2001: 3). Çünkü ekonomik ve ulaşılabilir bir ulaşım aynı zamanda, istihdam, ekonomik büyüme ve küresel ihracatın temelini sağlayarak, vatandaşlara yaşam kalitesi için gerekli olan kaynakları ve mobiliteyi sağlamaktadır (European Commission, 2010: 5).

Ulaşım sektörü, AB'de bu tür pozitif dişsallıklar sağlarken beraberinde negatif dışsallıklar da getirmektedir. Çünkü ulaşım sektörü, AB'de toplam enerji tüketiminin yaklaşık \%25'ine, sera gazı emisyonlarının \%20-34'üne (Morchain ve Fedrizzi, 2011: 5), trafik sıkışıklığı kaynaklı da yıllık yaklaşık 100 milyar Avrupa Birliği avrosu (EUR) maliyete neden olduğu ifade edilmektedir (Happiest Minds, 2014: 3). Ulaşım alanında yaşanan sıkıntılar ise özellikle kentlerde yaşayan tüm bireyleri olumsuz olarak etkilemektedir. Çünkü trafikten kaynaklanan sebeplerle oluşan mağdurlar ve bunların yakınları üzerinde meydana getirdiği fiziksel ve psikolojik etkiler oldukça ciddi boyutlara ulaşmaktadır. 
Yapılan bir araştırma, trafikte meydana gelen kazaların mağdurlar ve mağdur yakınları üzerinde ortaya çıkardığı etkileri; günlük işlere ilgi kayıp (\%72), sürüş yeteneği kaybı (\%70), kendine güven kaybı (\%49), kaygı krizi (\%46), intihar etme riski (\%37), bunalım (\%64), korkular (\%27), hazım şikâyeti (\%35), sinir (\%78), öç alma isteği (\%71) şeklinde ifade etmektedir (Işıldar, 2017: 87-88). Trafik esnasında ortaya çıkabilecek bu tür kazalarının söz konusu psikolojik ve fiziksel etkilerinin yanı sıra ülkelere olan maliyeti Gayri Safi Milli Hâsıla (GSMH) bazında \%2,5 seviyelerindedir (UB, 2011: 27). Bu anket sonucuna göre ortaya çıkan birçok psikolojik, fiziksel ve ekonomik etki ister ${ }^{\mathrm{i}}$ stemez olaya maruz kalan kişilerin dışında iş, eş, dost ve ülke ekonomisi gibi çok boyutlu negatif dışsallıklar ortaya çıkarmaktadır.

András Siegler (Avrupa Komisyonu Genel Müdürlüğü Araştırma Ulaştırma Direktörü), Eylül 2009 Stockholm'de yapılan AUS Dünya Kongresi’nde, AUS ve hizmetlerinin yaygın şekilde kullanımının trafik tıkanıklığını \%15, CO emisyonlarını \%20 ve trafik kazalarını da \%15 oranında azaltabileceği tahmininde bulunmuştur (European Commission, 2010: 5). İspanya ise AUS ile trafikte 2020 yılına kadar ölümleri milyonda 37 oranında azaltmayı, özellikle şehir içlerinde taşıtlarda sıfır ölüm oranı hedefi ile motosiklet kullanımından kaynaklı ölüm ve kazaları da \%20 azaltma gibi hedefler koymuştur (UDHB, 2014: 24, 29).

Avrupa çapında karayolları ağının (TERN) koridorlarında "EasyWay" finansman programı ile topluluklara, kırsal şebekelere ve toplu taşıma alanlarına yönelik ara yüzler dâhil olmak üzere, uyumlaştırılmış AUS’ların kullanımı hedeflenmiştir. Özellikle 2010/40/ $\mathrm{AB}$ Yönergesi'nin hedefleri sürdürülmektedir. EasyWay'de trafik kontrol sistemleri, trafik bilgi sistemleri, yük taşımacılığı alanında AUS, bilgisayarlar, trafik yönetimi ve trafik bilgi merkezlerinin teknik donanımlarının yenilenmesi / başlangıç donanımı, trafik verileri ve trafik bilgilerinin trafik bilgilendirme merkezleri ile AB Mobilite ve Ulaştırma Genel Müdürlügünün diğer merkezleri ile teknik donanım, deneyim değişimi, bilginin aktarılması ve ortak kuralların geliştirilmesinin hızlandırılması teşvik edilmektedir.

Sürdürülebilir ekonomik sistem ve çevre için AUS uygulamaları AB için önemli rol oynamaktadır. Çünkü AUS ve hizmetleri sayesinde birçok negatif dışsallığa (hava ve gürültü kirliliği, fosil yakıtlara bağımlılık, trafik tıkanıklığı, trafik kazaları ve taşımacılık vb.) çözümler üretilmektedir (Pojani ve Stead, 2015: 7793). Trafiğe dair bu tür sorunların giderilmesi adına AB, 2008 yılında AUS konusunda beş farklı tema esas alarak bir eylem planı hazırlamıştır. Bu plana göre (United Nations Economic and Social Commission for Asia and the Pacific (UNESCAP), 2015: 29); yol, trafik ve seyahate dair bilgilerin en iyi şekilde kullanılması, trafik ve yük yönetiminin kesintisiz yapılması, yol ve genel güvenliğinin sağlanması, araçların ulaşım altyapısına uyum sağlaması, AB'nin AUS koordinasyonu açısından verilerin korunmasının sağlanması şeklindedir (European Commision, 2010: 5).

AB’nin önemli ülkelerinden Almanya’da, AUS çerçeve yolu üç öncelikli alana ayrılmıştır. Bunlar (Europäischen Parlement und des Rates (EPR), 2010: 5); yol ve seyahat verilerinin optimal kullanımı, AUS hizmetlerinin trafik yönetimi alanlarında tutarlılığı, yük yönetimi 
ve trafik bilgisi ile trafik verimliliği ve güvenliği için AUS uygulamalarını kapsamaktadır. Almanya'da AUS'un çerçevesi yolunda somut olarak şu noktalar bulunduğu tespiti yapılmıştır (EPR, 2010: 14); kapsam, motivasyon, mevcut durum, ulusal strateji, roller ve sorumluluklar, 2020 yılına kadar öncelikli alanlar, Almanya’da AUS için eylem planları, AUS eylem planının uygulanması ve uygulanma süreci, karayolları taşımacılığı için AUS çerçevesini gözden geçirme sürecidir.

AUS bugüne kadar temel olarak, ulaşım sistemindeki endüstriyel, teknolojik inovasyon ve telematik bileşenleri ile (örneğin altyapı, araç veya kişisel mobil cihazlar) eşanlamlı olarak görülmüştür. Bununla birlikte kamu yararı konuları (politik, idari ve yönetim) teknolojik gelişmelerle (örneğin hukuki, örgütsel ve operasyonel hususlar ile sorumluluk sorunları ve ekipman taahhütleri gibi) eşit önemde olduğu ve Avrupa bağlamında yoğun olarak ele alınması ihmal edilmiştir (Böhm vd., 2011: 11).

AB dışında ülkelerde de AUS uygulamasının birçok nedeni bulunmaktadır. Örneğin, Avustralya'da AUS uygulanmasinın nedeni (Standing Council on Transport and Infrastructure, 2012: 3); ülke bazında karayolu taşımacılı̆̆ının toplam sera gazı emisyonlarının \%14'ünden sorumlu olması (trafikteki dur-kalktan kaynaklı sera gazı emisyonunu \%30 daha fazla arttırmasına neden olması), yıllık kaza maliyetlerinin 27 milyar Avustralya doları (AUD)'na ulaşması, yük ve yolcu taşımacılığında öngörülen artış ile karayolları yükünün 2030 yılına kadar \%80 artacağı, 2020 yılı itibariyle, karayolu trafiğindeki tıkanıklıkların artışının verimlilik düşüşüne ve işgücü maliyetine (20 milyar AUD) neden olacağıdır. Ayrıca Avustralya'da yapılan bir başka çalışmada (2015 yılı için) trafik kaynaklı zaman kaybının 6 milyar AUD, iş kaybı maliyetinin 8 milyar AUD, ekstra araç işletim maliyetinin 1,5 milyar AUD, ilave olarak hava kirliliği maliyetinin ise 1 milyar AUD olduğu ifade edilmiștir. Toplamda 16,5 milyar AUD'lik bir maliyetin ortaya çıkacağ öngörülmekte olup 2030 yılı için öngörülen rakam ise 30 milyar AUD'dur (Australian Government Department of Infrastructure and Regional Development, 2015: 1; Australian Infrastructure Plan, 2016: 6).

Avustralya'da ulaşım alanında yaşanan bu sorunlara karşılık çözüm olarak sunulan AUS’un sağlayacağı faydalar oldukça fazladır. Bu konuda 1998 yılında yapılan bir çalışmada yapılan tahminler bile AUS'un potansiyelini gösterir mahiyettedir. Nitekim 1998 yılında yapılan çalışmada, 2012 yılına kadar AUS’un kaynak tasarrufunda meydana getirmesi muhtemel etkilerin en az 14,5 milyar AUD (tıkanıklık ve zaman konusunda 7,5 milyar AUD, verimlilikte 3,2 milyar dolar AUD, güvenlikte 3,8 milyar AUD ve çevre konusunda 63 milyon AUD) olacağı ifade edilmektedir (Access Economics, 2009: 16-17).

Avustralya gibi Singapur'da da meydana gelen negatif dışsallıklardan birisi olan CO2 miktarının \%14,5'inden ulaştırma alanı sorumludur (Lee vd., 2016: 4; C40 Cities Siemens, 2014: 1). Trafik tıkanıklığı ve bundan kaynaklı sorunların birçok ülkeye göre düşük olsa da yine de önüne geçmek için AUS oluşturulmuştur. Özellikle Singapur'da AUS altyapısı, 161 km'lik anayol ve tünelleri kapsamaktadır. Yol tıkanıklıklarını yönetmek için Elektronik Yol Fiyatlandırma (ERP) Sistemini kullanan dünyadaki ilk şehir Singapur'un 
başkenti olan Singapur'dur. Aynı zamanda dünyanın ilk akıllı ülke olma arzusuna da sahip ülkesidir (Lee vd., 2016: 3).

Singapur'un AUS konusundaki çabaları 2013 yılında Akıllı Şehir Altyapısı kategorisinde Akıllı Ulaşım Sistemleri ödülü almasını da sağlamıştır. Singapur sahip olduğu akıllı çözümler sayesinde dünyadaki en düşük trafik tıkanıklı̆̆ı oranlarından birine sahiptir (C40 Cities Siemens, 2014: 2). Ayrıca AUS alanında yapmış olduğu yatırımlar geri dönüş de sağlamaktadır. Örneğin, 1998 yılında yaklaşık olarak 115 milyon Amerikan doları (USD)'na kurulan ERP'nin 2003 yılındaki yıllık geliri 45 milyon USD iken 2010 yılında 90 milyon USD’ye yükselmiştir. Bu yönüyle ERP yatırım bedelini kısa sürede amorti etme potansiyeli ile oldukça verimli bir yatırım olmanın yanı sıra trafik yoğunluğunu \%13 azaltırken, araçların ortalama hızında ise \%20'lik bir artış sağlamıştır. Singapur'da 2008 yllından beri uygulamada olan Park Rehberliği Sistemi sayesinde ise (elde edilen veriler kent genelinde bulunan 30 bilgi panelinden sağlanmakta olup) sürücülerin park etme süresi ve yakıt maliyetlerini düşürdüğü tespit edilmiştir (UDHB, 2014: 37; C40 Cities Siemens, 2014: 3).

İngiltere'de, Ekonomi ve İş Araştırmaları Merkezi INRIX yapmış olduğu bir araştırmada, 2017 yılında trafik yoğunluğunun sürücülere olan zaman ve parasal maliyeti hesaplanmıştır. Burada ortalama zaman maliyetinin yaklaşık 31 saat, parasal maliyetinin de 1.168 İngiliz sterlini (GBP) olduğu tahmin edilmiştir. Bunun İngiliz ekonomisine maliyetinin ise 2030 yılına gelindiğinde toplamda \%63 oranında artacağı, yani 21,4 milyar GBP seviyelerinde olacağ1 öngörülmüștür (BBC News, 2018).

İngiltere aslında dünyanın AUS konusunda önde gelen ülkelerindendir. Çünkü MIRA, AUS ve hizmetlerini kullanmaktadır. MIRA, çok karmaşık kontrol sistemlerini sağlayan askeri düzeyde bir programdır (Singh vd., 2014: 37). İngiltere'de AUS ile ilgili yapılanlara (Khorasani, 2013: 110-111; İstanbul Bilişim ve Akıllı Kent Teknolojileri (İSBAK), 2018: 4-23); Kentsel Trafik Yönetimi ve Kontrolü, Transport Direct, Otoyol Seyahat Bilgisi, Clear Zones, Akıllı Kartlar, Aktif Trafik Yönetimi ve Oyster Card örnek verilebilir.

AUS’un trafik kaynaklı sorunları azaltmada İngiltere için Londra’da yapılan bir uygulama ve sonuçları şu şekildedir; Londra'da (2000'li yılların başında) trafik bakımından tıkanık bölgelerin elektronik olarak ücretlendirmesi şeklinde bir uygulama başlatılmıştır. Bu uygulamanın ilk 6 aylık dönem sonunda çıktılarına bakıldığında (Sayeg ve Charles 2005: 19); bölgedeki trafiği \%10-15 oranında azalttığı, ücretlendirmenin uygulandığ bölgede trafik tıkanıklığını \%30 oranında düşürdüğü, seyahat süresine olan güveni \%30 oranında yükselttiği, bölgeye gelen günlük araç sayısının da 200.000'den 60.000'e düştüğü görülmüştür.

Ulaşım alanında negatif dışsallıkların yaşandığ Hindistan'da her yıl ortalama 500 bin trafik kazası meydana gelmektedir. Bu kazalarda ise yaklaşık 600 bin kişinin yaralandığ 1,150 bin kişinin ise öldüğü ifade edilmektedir. Yaralanma ve ölüm olaylarının yaşandığ 1 bu kazaların parasal karşılığı ise 20 milyar 
USD’dir (Happiest Minds, 2014: 3). Hindistan Kalkınma Enstitüsü ile Kalküta ve Hindistan Ulaştırma Şirketi tarafından yürütülen ortak bir araştırmada, Hindistan'da yük nakliye araçlarının ücretlendirme istasyonlarında karşılaştıkları operasyonel verimsizliklerin toplam maliyetinin 5,4 milyar USD, zaman kaybından kaynaklı maliyetin 600 milyon USD ve ekstra yakıt maliyetinin 4,8 milyar USD'yi bulduğu ifade edilmektedir (UNESCAP, 2015: 17). Araç sayısında her geçen gün yaşanan artış ise trafik sıkışıklığını, emisyon salınımında artışı ve büyük şehirlerde gürültü kirliliğini daha da arttıracağı düşünülmektedir. Bu olumsuzlukları önlemek adına Hindistan'da AUS için 5 yıl içinde 60 milyar, 20 yıl içinde de yaklaşık 390 milyar EUR yatırım yapılması beklenmektedir (Happiest Minds, 2014: 12).

Japonya'da da benzer şekilde negatif dışsallık yayan ulaştırma sektörü, Avustralya ve Singapur'dakinden daha fazla CO2 salınımına neden (\%20) olmaktadır. Trafik kazaları kaynaklı yaralanmaların sayısı da oldukça (800.000) fazladır. Kazaların parasal tutarı ise yıllık 3 trilyon Japon yeni (JPY) düzeyindedir. Ayrıca trafik tıkanıklığının Japonya’ya yıllık 5,3 milyar saatlik bir zaman kaybına neden olduğu (maddi olarak karşılı̆̆ının 12 trilyon JPY) da belirtilmektedir. Trafik tıkanıklı̆̆ı maliyetinin, trafiğin olmadığı zamanlara göre 2 katı kadar olması maliyetleri daha da arttırmaktadır. Japonya'nın nüfusunun yaşlı olması, sürüş esnasında karar verme ve tanımlama sürecinde gecikmelere neden olmaktadır. $\mathrm{Bu}$ ve benzeri nedenlerle Japonya, trafik tıkanıklığı azaltma konusunda bilgi ve iletişim teknolojilerinin uygulanmasında öncü konumda olmuştur (Washimi vd., 2014: 10; Holborn, 2002: 4; Hayakawa, 2013: 1; Japan Traffic Management Technology Association (JTMTA), 2017: 30,35).

Trafik sıkışıklığı, kirlilik ve trafik kazaların artması gibi nedenler ise Japonyada ilgili tarafları bir masaya oturtarak, artan bu sorun alanlarına çözümler bulmak için AUS kurulmasını sağlamıştır. Japonya’da AUS ile ilgili endüstri, özel sektör, yükseköğretim ve ilgili kuruluşların temsilcileri bir araya getirilmesi sağlanmıştır. AUS ile trafik sıkışıklığı, kirlilik ve trafik kazaların artmasından kaynaklanan sorunlara modern (en son) iletişim ve kontrol teknolojileri ile yardım sağlanmaktadır. Bununla birlikte, yollar ve motorlu taşıtlar hakkında bilgiler sürücülere iletilmektedir. AUS, enerji tasarrufu yaparak çevreyi korumakta, seyahat için ideal şartlar yaratarak trafik kazaları ve tıkanıklıkları da azaltmaktadır (Hanreich, 2003: 1).

AUS, sadece akıllı yol rehberliğini esas almamakta aynı zamanda demiryolu, havayolu ve deniz taşımacılığı gibi çeşitli ulaşım araçlarının da işbirliğine olanak tanıyarak, sorun alanlarının ortak çözümüne katkı sağlamaktadır. Japonya’da AUS, devlet düzeyinde bir proje haline gelmiştir. AUS alanında, birkaç on yıl içinde araştırma ve geliştirme alanlarının teşvik edilmesi, yeni yol ve ulaşım sistemleri alanlarının kurulması ile yeni iş imkânlarının geliştirilmesi hedeflenmektedir. Japonya’da 1995 yılında yapılan bir çalışmada AUS için 30 yılda öngörülen hedefler (Hanreich, 2003: 1); ağır trafik kazalarının sayısını \%50 azaltmak, trafik tıkanıklığını önlemek, araçların yakıt tüketimini düşürmek ve araçların her biri için CO2 emisyonlarını \%15 indirerek, şehirlerdeki azot oksitlerin \%30 oranında azaltılmasını sağlamaktır. Japonya'da uygulanan AUS bileşenlerinin ortaya çıkardığı faydalar Tablo 2'de 
özetlenmiştir.

Tablo 2: Japonya'daki AUS Bileșenlerinin Ortaya Çıkardığı Faydalar (1997)

\begin{tabular}{|c|c|c|}
\hline AUS Kategorisi & $\begin{array}{l}\text { Faydalar } \\
\text { (Bin JPY) }\end{array}$ & Azalan Kaza Sayısı \\
\hline Trafik kontrol merkezinin olması & 35.406 & 651 \\
\hline Alan kontrolünün geliştirilmesi & 55.312 & 1.481 \\
\hline Bağlantılı sistemlerin geliştirilmesi & 48.788 & 1.234 \\
\hline Yarı aktif kontrolün geliştirilmesi & 4.684 & 5.508 \\
\hline Sağa dönüşler için trafik kontrolünün geliştirilmesi & 13.738 & 7.280 \\
\hline Aşırı hız önleme cihazı & - & 7.102 \\
\hline Yaşlı ve engelliler için sensörlerin geliştirilmesi & - & 6.427 \\
\hline
\end{tabular}

Kaynak: (Japan Traffic Management Technology Association, 2017: 63).

Ulaşım alanında birçok negatif dışsallığın yaşandığı ülkelerden birisi de Güney Kore'dir. Çünkü 2000 yılında trafik tıkanıklığı maliyeti 1999 yılına göre 2 trilyon Güney Kore wonu (KRW) artışla 19 trilyon KRW ulaşmıştır. Trafikte meydana gelen kazalar esnasında yaralanma veya ölüm sayısı 350.000 olmuştur. Trafikte meydana gelen ölüm ve yaralanma ile bağlantılı sosyal maliyetler ise 11 trilyon KRW'a ulaşmış, taşıt araçlarının neden olduğu hava kirliliği ile ilgili sosyal maliyetler ise 1,6 trilyon KRW olarak tahmin edilmiştir (Knowledge Sharing Program (KSP), 2014: 22). Ulaşım alanında araç kullanımının bu denli yükselmesi gürültü kirliliği, yol yapımında kullanılan arazi miktarının artması gibi diğer negatif dışsallıkları da birlikte getirmiştir (Allen, 2013: 4-5). Bu öngörülen ve görülmeyen birçok olumsuz durum ile negatif dişsallıklar aslında Güney Kore'de yol güvenliği ve trafik koşullarını iyileştirme adına AUS’a geçilmesine de neden olmuştur (KSP, 2014: 22).

AUS konusunda ise Güney Kore'de birçok düzenleme yapılmıştır. Bu konuda sadece AUS sayesinde her geçen gün tanınırlığı artan Anyang şehrinde yapılanlar Tablo 3'de verilmiştir. 
Tablo 3: Anyang Şehrindeki Bazı AUS Servisleri

\begin{tabular}{ll}
\hline \multicolumn{1}{c}{ Alan } & \multicolumn{1}{c}{ Servisler } \\
\hline Trafik bilgi toplama ve yayma & $\begin{array}{l}\text { CCTV, Otobüs Bilgi Sistemi (BIS), WEB, görüntü dedektörleri ve } \\
\text { sinyal kontrol dedektörlerinden elde edilen bilgileri toplamaktadır. }\end{array}$ \\
\hline Trafik bilgisi işleme ve analizi & $\begin{array}{l}\text { - Toplanan ham verilerin uygun algoritması kullanılarak üretilen ve } \\
\text { analiz edilen bilgileri sağlamaktadır. }\end{array}$ \\
\hline Trafik bilgisinin tedarik edilmesi & $\begin{array}{l}\text { Vatandaşlar ve dis̆tatistik bilgisi ve model bilgisi üretmektedir. } \\
\text { tadır. }\end{array}$ \\
\hline Bakım ve yönetim faaliyeti & Yol durumunun kontrolünü ve yönetimini yapmaktadır. \\
\hline Elektronik harita & WEB için elektronik harita bilgilerini sağlamaktadır. \\
\hline Merkezi işlemler yönetimi durinini sağlamak-
\end{tabular}

Kaynak: (Lee vd., 2016b: 6).

Güney Kore’de, AUS’un uygulanmaya başladığı 2000 yılından itibaren 10 yıl içinde, trafik tıkanıklığındaki iyileşme yıllık 11,8 trilyon KRW sosyal fayda sağlayacak düzeye gelmiştir. Ayrıca trafik hızında \%15-20 arasında iyileşmenin olduğu, yollarda acil müdahale gereken olaylara hızla ulaşılabilmesi sayesinde yaralanma ve ölüm olaylarının boyutlarının azaldığı, birçok ikincil kazanın da ayrıca önlendiği tespit edilmiştir (KSP, 2014: 23). 2030 yılına kadar da Güney Kore'de; yeşil ulaşım modu payının \%80'e çıkarılması, yeşil ulaşım oranını \%30 arttırılması, trafikteki araç sayısını \%30 düşürülmesi, toplu taşıma araçlarını trafik tıkanıklığı kaynaklı kullanım süresini \%30 azaltarak insanların toplu taşımaya yönlendirilmesi gibi hedefler konulmuştur (Seoul Metropolitan Government, 2014: 5).

Ulaştırma alanında bir başka sorun yaşayan ülke ise Çin’dir. Çünkü hızlı ekonomik büyüme ile birlikte karışık olan araç ve bisiklet trafiği daha da karışık hale gelerek, trafik güvenliği ve akışı noktasında sorunlarla karşılaşmıştır (Li ve Tang, 2009: 5). Trafikte yaşanan sorunlar ise başta trafik sıkışıklığı olmak üzere, güvenlik, çevresel kirlilikler gibi birçok negatif dışsallığg beraberinde getirmiştir. Çin'de araç sahipliğinde \%15’lik bir artışa karşın, kentsel alanda yol yapımının \%3 oranında artması durumu özetler niteliktedir (Intelligent Transportation System Association of Shenzhen (SZITS), 2017: 5). Yayınlanan bir raporda (Dünya Bankası) da kentsel ulaştırmada yaşanan tıkanıklığın enerji kullanımı ve sera gazı emisyonunu \%4-6 arasında arttırdığı da ifade edilmektedir (PRTM Management Consultants, 2011: 1). Büyümesini sürdürülebilir kılmak isteyen Çin hükümeti, enerji tasarrufu sağlamak ve sera gazı emisyonlarını azaltmak konularını ise kendisine görev saymaktadır (McKinsey\&Company, 2009: 21). Ulaşım alanında yaşanan sorunlar ve 
zorunluluk, Çin'in ekonomik ve sosyal anlamda öngördügü hedeflere ulaşması noktasında aslında AUS uygulanmasını da bir anlamda zorunlu kılmıştır. Bu nedenle Çin'de, akıllı yaklaşımı benimseyen ilk sektörlerden birisi ulaşım olmuştur (European Union Small and Medium-sized Enterprises, 2015: 12).

Çin'de ulaşımda AUS’un uygulanmaya başlanmasına rağmen ülke olarak halen ABD, Japonya ve Avrupa gibi gelişmiş ülkelerle karşılaştırıldığında, AUS endüstrisi başlangıç düzeyindedir. Bu da acilen AUS konusunda ileri düzeydeki ülkelerdeki gelişmiş akıllı trafik konseptlerini, teknolojilerini, ürünlerini ve kentsel ulaşım ayarlamasının yeniden yapılması gereksinimini doğurmaktadır (SZITS, 2017: 5-6). Zira AUS noktasında Çin’in Shenzhen şehrindeki 398 numaralı otobüs hattında uygulamaya konan Akıllı Toplu Taşıma Sevk Sistemi ile elde edilen pozitif katkılar bile AUS ve hizmetlerinin ne tür olumlu gelişmelere sebep olabileceği noktasında fikirler vermektedir. Bunlar; aylık ortalama yolcu sayısında \%0,92 artış, otobüs hareket saatlerinin dakikliğinde \%2'lik iyileşmedir. Ayrıca hız ihlallerinde \%9'luk azalma, istatistiklerin hazırlanmasında \%10'luk iyileşme, hareket memuru sayısında \%6'lık düşüşün sağlanmasının getirdiği maliyet avantajı (iş kaybı olarak olumsuz da değerlendirilebilir), yolcular için bekleme süresindeki (0,4 dakika) iyileşme, yolcu şikâyetlerindeki \%2 düşüş ve yolcu konforundaki \%5 artış olarak gösterilmektedir (International Organization for Standardization, 2014: 24-28).

Birçok ülke gibi trafik konusunda sorun yaşayan bir başka ülke de ABD'dir. Çünkü ABD'de her yıl çoğunlukla sürücü hataları kaynaklı 6 milyondan fazla trafik kazasının meydana geldiği, bu kazalarda ortalama 42 bin kişinin öldüğü, 3 milyona yakın insanın yaralandığ ve maliyetinin de 230 milyar USD'den fazla olduğu tahmin edilmektedir (Auer vd., 2016: 26). İşin parasal boyutunun yanı sıra bir de sosyal boyutunun olduğunun unutulmaması gerekmektedir. Ayrıca ulaşım sektörü ABD'deki toplam sera gazı emisyonlarının da önemli bir oranından (yaklaşık \%28) sorumludur. Ulaşımdan kaynaklanan emisyon miktarı ise diğer sektörlerden daha hızlı bir şekilde büyümektedir bu da konunun önemini daha da arttırmaktadır (Huawei, 2016: 7). 2011 yılında yapılan bir çalışmada, trafik tıkanıklığı kaynaklı olarak Amerikalıların ekstradan 5,5 milyar saat harcadığı ve 2,9 milyar galon yakıt tükettiği (Oh vd., 2015: 11), bazı şehirlerinde trafikte kaybedilen zamanın daha büyük boyutlara ulaştığı ifade edilmektedir. ABD'de ortalama bir yolcu 42 saat zaman harcarken New Yorklularda bu süre 89 saati geçmektedir (İSBAK, 2018: 7). Bu nedenle ABD'de 1996 yılından 2015 yıllına kadar olan zaman zarfinda yapılması planlanan 300-350 milyar USD, AUS yatırımlarıyla trafik kaynaklı negatif dışsallıklarda; zaman kaybı (\%41), kazalarda azalma (\%42), işlem maliyeti (\%6) düşüşü ile yakıt ve emisyon tüketim (\%6) düzeyinde önemli düşüşler hedeflenmiştir (Ener, 1999: 91). AUS’un ortaya çıkardığı kuşkusuz diğer pozitif sonuçlarda söz konusudur. Örneğin, Atlanta’da olay yönetimi sisteminin bir parçası olan NAVIGATOR sayesinde olay yerine ulaşma süresi 21 dakikadan 10 dakikaya düşmüştür. Berkeley'de yürütülen bir çalışma neticesinde sadece mevcut sinyalizasyon sürelerinin optimize edilmesinin (koordine edilen bir sinyalizasyon sistemi) bile yakıt tüketimini yaklaşık \%8 civarında azalttığı, ulaşım sürelerini ise $\% 7,7$ düşürdügü, gecikmelerde de \%13,8 civarında bir azalmanın olduğu görülmüştür (Ilıcalı vd., 2016: 12,15). 


\section{SONUÇ}

Trafik kaynaklı negatif dışsallıkların giderilmesi trafik sorununun ortadan kaldırılması ya da en azından minimize edilmesine bağlıdır. Trafik sorununun çözümü için kentlerin ulaşım sistemlerine yeni yollar ve köprüler eklenmesi akla gelebilir. Ancak bu çözüm parasal ve teknik başta olmak üzere birçok noktadan sekteye uğramakta ve her zaman mümkün olmamaktadır. Ayrıca yeniden inşa faaliyetlerinin sürekli artması ulaşım yapısını bir kısır döngüye sokarak ulaşım sisteminin geleceğini olumsuz etkilemekte ve kaynakların verimsiz kullanımına neden olmaktadır. Esas çözüm ise insanların trafikteki düşünme ve karar verme yüklerini hafifleten bilgi ve iletişim teknolojileri destekli akıllı ulaşım çözümlerinin kullanımının yaygınlaştırılmasından geçmektedir. Çünkü ulaşım sadece alıcı ve satıcıyı ilgilendiren bir piyasa işlemi olmanın ötesine geçerek, içinde bulunulan toplumu (hatta canlı-cansız yaşamını) etkileyen bir boyuta taşınmaktadır. $\mathrm{Bu}$ da ulaşım politikalarının AUS ile de desteklenmesi gereksinimini doğurmaktadır. Çünkü ulaşım alanında sağlanacak yenilikler sürdürülebilir, verimli ve rekabetçi bir hareketlilik için bir zorunluluk niteliğini taşımaktadır.

Çok iyi tasarlanmış bir ulaşım sistemi ve hizmetleri, mekânı ve zamanı ulaşılabilir kılarak (insanlar ve malları bir araya getirerek) yüksek bir yaşam kalitesinin de ön koşulunu oluşturmaktadır. AUS ile akıllı araç ve yol sistemlerinin birbirleriyle işbirliği yapması sağlanarak; trafikte tıkanıklık, kazalar, yaralanmalar, sağlık harcamaları ile maddi kayıplar da azalmalar sağlanacaktır. Ayrıca trafikteki tıkanıklıktaki azalma neticesinde yaşanan stres, aşırı yakıt tüketimi ve çevresel kirlilikler noktasında birçok negatif dişsallığın da önüne geçilerek yaşam kalitesini yukarılara çekmek mümkündür. Çünkü AUS; verimli, güvenli ve çevre dostu ulaşıma katkı sağlamaktadır. Bu konuda AB ya da Avustralya, Japonya, Çin, Güney Kore, Singapur, ABD gibi birçok ülke de AUS konusunda harcamalar yapılmakta ve geleceğe ilişkin pozitif çıktılar beklenmektedir.

AUS’a yapılan harcamalar Singapur örneğinde olduğu gibi kısa sürede kendisini amorti edebilmektedir. Kendisini amorti etmesinin dişında trafik yoğunluğunda (\%13), araçların trafikte akış hızında da (\%20) iyileşme sağlayabilmektedir. En basitinden Park Rehberliği Sistemi sayesinde sürücülerin kısa sürede park etmesi sağlanmakta, yanlış park önlenmekte, yakıt tasarrufu sağlanmakta, yanlış parktan kaynaklı trafik kazaları, zaman kaybı gibi birçok negatif dışsallı̆̆ın da önüne geçilebilmektedir. Ancak AUS yoğun teknoloji kullanılmasını gerektirdiği için teknoloji kaynaklı sağlık problemlerine, iş kayıplarına, teknolojik kirlenmeye, tembelliğe, özel yaşamı ihlale ya da AUS bilgi toplama ve işleme üzerine kurulduğu için herkesi ilgilendiren genel bilgilerin korunması noktasında endişelere neden olabilmektedir.

AUS’un, üretici ve tüketici dışında gerçekleşen bu pozitif ve negatif dışsallıklarının bir bütün olarak değerlendirilmesi gerekmektedir. Bu çalışma kapsamında özellikle pozitif dışsallıklarının daha yüksek olduğu gözlenmiştir. AB'de dâhil olmak üzere incelenen birçok ülkede yoğun bir şekilde AUS kullanılması da bu gerçeği doğrular niteliktedir. Ancak AUS’un sadece bu pozitif çıktılarına odaklanıp, negatif dışsallıklarını görmezden 
gelmemek gerekir. AUS’un ortaya çıkardığı negatif dışsallıklarına giderilmesi için çözümler üretmenin AUS’un daha sağlıklı gelişimine hizmet edeceği unutulmamalıdır.

AUS’un yaydığı dışsallıkların daha geniş bir alana yayılabilmesi için AUS teknoloji ve uygulamalarının gelişmiş olduğu ülkelerin yanı sıra nispeten daha az gelişmiş ülkelerde de yaygınlaştırılması gerekmektedir. Bu ülkelerde, AUS teknolojilerinde dışa bağımlılıklarının azaltılması, AUS konusunda uzman işgücünün yetiştirilmesi, mevzuat ve standartların oturtulması ile kurumlar arası senkronizasyonun sağlanması AUS'un geliştirilmesi adına oldukça önem arz etmektedir. Ayrıca AUS çatı birliklerinin kurulması, her yıl düzenlenen AUS dünya kongresine olan katılımın arttırılmasının sağlanması ile AUS hizmet ve uygulamalarının yaygınlaştırılması sağlanacak ve ülkelerin ulaşım sistemleri gelişecektir. Böylece trafik kaynaklı negatif dışsallıkların giderilmesi ve bu noktada pozitif dışsallıkların artması sağlanmış olacaktır. 


\section{KAYNAKÇA}

Access Economics. (2009). The Economics Benefits of Intelligent Technologies. Report by Access Economics Pty Limited for IBM.

Akgüngör, A. P. ve Demirel, A. (2004). Türkiye’deki Ulaştırma Sistemlerinin Analizi ve Ulaştırma Politikaları, Pamukkale Üniversitesi Mühendislik Bilimleri Dergisi, Cilt: 10, Sayı: 3, 423-430.

Allen, H. (2013). Bus Reform in Seoul. Republic of Korea, Case Study Prepared for Global Report on Human Settlements.

Arucu, M. (2017). Güney Kore, Japonya, ABD, AB Ülkelerinin AUS Konusundaki Vizyon, Strateji, Politikaları ve Türkiye'deki AUS Beklentileri. Akıllı Ulaşım Sistemleri Çalıştayı ve Sonuç Raporu, Bandırma Onyedi Eylül Üniversitesi, Bandırma, 27-34.

Auer, A., Feese, S. ve Lockwood, S. (2016). History of Intelligent Transportation Systems. Report No. FHWA-JPO-16-329, U.S. Department of Transportation.

Australian Government Department of Infrastructure and Regional Development (AGDIRD). (2015). Bureau of Infrastructure, Transport and Regional Economics. Information Sheet, ISSN: 1440-9593.

Australian Infrastructure Plan (AIP). (2016). Priorities and Reforms for Our Nation's Future. Report, Australian Government, Infrastructure Australia.

Barth, M., Wu, G. ve Boriboonsomsin, K. (2015). Intelligent Transportation Systems for Improving Traffic Energy Efficiency and Reducing GHG Emissions from Roadways, A White Paper from the National Center for Sustainable Transportation, National Center for Sustainable Transportation.

BBC News. (2018, 6 Şubat). UK must Tackle 'Astonishing' Cost of Congesiton, Study Says, Erişim adresi (10.04.2018): https://www.google.com.tr/amp/s/www.bbc.co.uk/ news/a mp/uk-4294825 9

Beckett-Camarata, J. (2005). Handbook of Public Sector Economics, Donijo Robbins (Ed.), Michigan: Taylor\&Francis.

Benk, S. (2007). Kentiçi Ulaşım Sonucu Oluşan Negatif Dışsallıklar ve Önleme Yolları, T.C. Uludağ Üniversitesi, Sosyal Bilimler Enstitüsü, Maliye Anabilim Dalı, Maliye Teorisi Bilim Dalı, Doktora Tezi, Bursa.

Böhm M., Flechl, B., Menzel, G., Pfliegl, R., Russ, M. ve Zwick, K. (2011). IVS-Aktionsplan Österreich, Strategie zur Umsetzung eines Intelligenten Verkehrssystems in Österreich, Bundesministerium für Verkehr, Innovation und Technologie (bmvit), Wien.

C40 Cities Siemens (C40). (2014). City Climate Leadership Awards. Singapore, Republic of Singapore.

Conway, E. (2015). Gerçekten Bilmeniz Gereken 50 Ekonomi Fikri, Ankara: Domingo Yayınevi. 
Durmuş, M. (2008). Kamu Ekonomisi, Ankara: Gazi Kitabevi.

Eicher, A. (2015). Nächste Ausfahrt: intelligente Verkehrssysteme, Titelthema: Transport, Logistik, Verkehr, gis.Business 2/2015, 8-13.

Ener, E. (1999). ITS ve Bolu Dağı Hava Durumu Ön Bilgilendirme Sistemi. II. Ulaşım ve Trafik Kongresi-Sergisi, 90-98.

Europäischen Parlement und des Rates (EPR). (2010). Status und Rahmenbedingungen für Intelligente Verkehrssysteme (IVS) in Deutschland, Artikel 17 (1) der Richtlinie 2010/40/EU.

European Commission. (2010). Intelligent transport systems, EU-funded research for efficient, clean and safe road transport, Directorate-General for Research Transport, EUR 24504, Belgium.

European Union Small and Medium-sized Enterprises (EUSME). (2015). Smart Cities in China. Sector Report, China-Britain Business Council,

Ezell, S. (2010, January). Intelligent Transportation Systems, The Information Technology \& Innovation Foundation.

Geßner C. ve Weinreich, S. (1998, Juli). Externe Kosten des Straße-und Schienenverk ehrslärmsam Beispiel der Strecke Frankfurt - Basel, Dokumentation Nr. 98-08, Zentrum für Europäische Wirtschaftsforschug GmbH (ZEW).

Hanreich, G. (2003). Intelligente Transport Systeme, 10th World Congress and Exhibition on Intelligent Transport Systems and Sevices, 16-20 November 2003, Madrid, Spain, News form Jama Europäische Ausgabe, JAMAktuell Special, Japan Automobile Manufacturers Association, Inc. Jahrgang 13 Nummer 3, Mai-Juni 2003, s. 1. 1-4.

Happiest Minds. (2014). Enabling Intelligent Public Transportation Using IOT.

Hayakawa, K. (2013). Japan: Intelligente Transport Systemen in de Logistiek. Innovatie Attache Tokio, Agentschap NL Ministerie van Economische Zaken.

Hindriks, J. ve Myles, G. D. (2013). Intermediate Public Economics, Second Edition, The MIT Press.

Holborn, S. (2002, July). Intelligent Transportation Systems in Japan. Tokyo: Technische Universitat Darmstadt.

Huawei. (2016). Smart Transportation. China.

Hyman, D. N. (1993). Public Finance, A Contemporary Application of Theory to Policy, Fourth Edition, United States of America: The Dryden Press.

Ilıcalı, M., Toprak, T., Özen, H., Tapkın, S., Öngel, A., Camkesen, N., Kantarcı, M. (2016). Akıc1-Güvenli Trafik için Akıllı Ulaşım Sistemleri, Erişim adresi: http:// ww4.ticaret.ed u.tr/ulastirma/wp-content/uploads/sites/85/2016/05/B\%C4\%B0L D\%C4\%B0R\%C4\%B 0-Ak\%C4\%B1ll\%C4\%B1-Ula\%C5\%9F\%C4\%B1m-SistemleriUygulamalar\%C4\%B1 n\%C4\%B1n-Trafik-G\%C3\%BCvenli\%C4\%9Findeki-Yeri-ve- 
\%C3\%96nemi-\%C3\%9C lkemizdeki-Uygulamalar.pdf

Intelligent Transportation System Association of Shenzhen (SZITS). (2017, 11 Kasim). Erişim adresi: http://www.yumpu.com/en/document/view/28619420/intelligenttrans portation-system-association-of-shenzhen-urba-2000

International Organization for Standardization (ISO). (2014). Non-economic Benefits of Standards. Shenzhen Transport Commission, China, Switzerland.

Işıldar, S. (2017). Ülkemizde Okul Servis Araçları Faaliyetlerinde Güvenliği Artıracak Yurtdışından Örnekler. 7. Karayolu Trafik Güvenliği Sempozyumu ve Sergisi, 2016 Sunulan Bildiriler, Şenol Yaprak (Ed.), 78-90.

ITS Deutschland. (2017). Deutsche Gesellschaft für Intelligente Verkehrssysteme-ITS Deutschland e.V., 09/2017.

İstanbul Bilişim ve Akıllı Kent Teknolojileri A.Ş. (İSBAK). (2018). A Guide to Intelligent Transportation Systems \& Best Practises. A Frost \& Sullivan White Paper.

Japan Traffic Management Technology Association (JTMTA). (2017, 18 Ekim). Intelligent Transportation Systems, ITS Developed by Japanese Police, Erişim adresi: http:// www.tmt.or.jp/research/pdf/its-e.pdf

Kargı, V. ve Yüksel, C. (2010). Çevresel Dışsallıklarda Kamu Ekonomisi Çözümleri, Maliye Dergisi, Sayı 159, Temmuz-Aralık, 183-202.

Khorasani, G., Tatari, A., Yadollai, A. ve Rahimi, M. (2013). Evaluation of Intelligent Transport System in Road Safety. International Journal of Chemical, Environmental \& Biological Sciences, (IJCEBS), Volume: 1, Issue: 1, 110-118.

Kirmanoğlu, H. (2014). Kamu Ekonomisi Analizi, İstanbul: Beta Yayınları.

Klarl, T. (2013). Einführung in die Finanzswissenschaft Externe Effekte, Universität Augsburg, Sommersemester.

Knowledge Sharing Program (KSP). (2014). 2013 Modularization of Korea’s Development Experience: Establishment of Intelligent Transport Systems (ITS).

Kumar, M., Albert, S. ve Deeter, D. (2005, April). A Summary of Rural Intelligent Transportation Systems (ITS) Benefits as Applied to ODOT Region 1, Oregon Department of Transportation Region 1.

Lee, S. K., Kwon, H. R., Cho, H., Kim, J. ve Lee, D. (2016, June). International Case Studies of Smart Cities: Singapore, Republic of Singapore. Discussion Paper No IDB-DP-462, Inter-American Development Bank.

Li, L. ve Tang, S. (2009). Intelligent Transportation Systems in China. IEEE Intelligent Transportation Systems Magazine, Summer.

McKinsey\&Company. (2009). China’s Green Revolution, Prioritizing Technologies to Achieve Energy and Environmental Sustainability, Australia. 
Morchain, D. ve Fedrizzi, S. (2011, January). Strategising Sustainable Urban Mobility in EU Neighbour Countries. City Hall of Chisinau Municipality, European Union.

Möller, D. P. F. ve Vakilzadian, H. (2016). Cyber-Physical Systems in Smart Transportation, IEEE, 776-781.

Nilsson, M., Williander, M. ve Englund, C. (2012). Commercialisation of Intelligent Transportation Systems: The Case of Cooperative Systems, Procedia - Social and Behavioral Sciences, 48, 722-732.

Oh, J.-S., Kwigizile, V., Sun, Z., Clark, M. L., Kurdi, A. H. ve Wiersma, M. J. (2015). Costs and Benefits of MDOT Intelligent Transportation System Deployments Final Report. Transportation Research Center for Livable Communities Western Michigan University.

Öz, E. ve Buyrukoğlu, S. (2012). Negatif Dışsallıkların Önlenmesinde Çevresel Vergiler: Türkiye ve OECD Ülkeleri Karşılatırması, TİSK Akademi, 2012/11, 84-107.

Pojani, D. ve Stead, D. (2015). Sustainable Urban Transport in the Developing World: Beyond Megacities. Sustainability, 7, 7784-7805.

Prendergast Renée (1993), Marshallian External Economies, The Economic Journal, Vol.: 103, No: 417, 454-458.

PRTM Management Consultants (PRTM). (2011). The China New Energy Vehicles Program: Challenges and Oppurunities.

Ramos, A. L., Ferreira, J. V. ve Barcelo, J. (2012). Modelling \& Simulation for Intelligent Transportation Systems, International Journal of Modeling and Optimization, Vol. 2, No. 3, June.

Republic of Turkey Ministry of Transport and Communications (RTMTC). (2011, October). Country Report, Transportation in Turkey.

Rosen, H. S. (2005), Public Finance, 7. Edition, The United States: McGRAW-HILL International Edition.

Saatçioğlu, C. ve Yaşarlar, Y. (2012). Kentiçi Ulaşımda Toplu Taşımacılık Sistemleri ve İstanbul Örneği, Kafkas Üniversitesi, İktisadi ve İdari Bilimler Enstitüsü Fakültesi Dergisi, Cilt: 3, Sayı: 3, 117-144.

Seoul Metropolitan Government (SMG). (2014). Seoul Public Transportation.

Shaheen, S. A. ve Finson, R. (2013). Intelligent Transportation Systems, Reference Module in Earth Systems and Environmental Sciences, Elsevier, 2013.

Singh, G., Bansal, D. ve Sofat, S. (2014, January). Intelligent Transportation System for Developing Countries: A Survey. International Journal of Applications, Volume: 85, No: 3, 34-38.

Sönmez, S. (1987). Kamu Ekonomisi Teorisi, Ankara: Teori Yayınları. 
Standing Council on Transport and Infrastructure (SCOTI). (2012). Policy Framework for Intelligent Transport Systems in Australia.

Statistisches Bundesamt. (2013). Verkehr auf einen Blick, Statistisches Bundesamt, DeSTATIS wissen.nutzen, Wiesbaden.

Stiglitz, J. E. (1994), Kamu Kesimi Ekonomisi, Ömer Faruk Batırel (Çev.), 2. Basım, İstanbul: Marmara Üniversitesi Yayın No: 549.

T.C. Ulaştırma Bakanlığı (UB). (2011). Türkiye Ulaşım ve İletişim Stratejisi Hedef 2023, Ankara.

T.C. Ulaştırma Denizcilik ve Haberleşme Bakanlığı (UDHB). (2014). Ulusal Akıllı Ulaşım Sistemleri Strateji Belgesi (2014-2023) ve Eki Eylem Planı (2014-2016), Ankara.

Turner, S. W. ve Uludag, S. (2016). Intelligent Transportation as the Key Enabler of Smart Cities, IEEE/IFIP NOMS Workshop: International Workshop on Platforms and Applications for Smart Cities (PASC), 1261-1264.

United Nations Economic and Social Commission for Asia and the Pacific (UNESCAP). (2016). Intelligent Transportation Systems for Sustainable Development in Asia and the Pacific, Thailand.

Übelmesser, S. (2009/2010). Externe Effekte, LMU München, WS, Erişim adresi: www. fiwi.vwl.unimuenchen.de/lehre/archiv/vorlesungen/200910_allokation/allokation_ kap5.pdf

Washimi, K., Kuramoto, M., Hayasaki, T. (2014, April). Sumimoto Electric's Approach for Intelligent Transport Systems. SEI Technical Review, Number: 78, 8-13.

Yan, X., Zhang, H., Wu, C. (2012). Research and Development of Intelligent Transportation Systems, 11th International Symposium on Distributed and Applications to Business, Engineering \& Science, 19-22 October 2012, Guilin, China. 